\title{
先端医療を支える機能性薬物キャリアの開発
}

\author{
田畑泰彦
}

\section{Development of Functional Drug Carriers to Realize Advanced Medical Therapy}

\author{
Yasuhiko TABATA \\ Department of Biomaterials, Field of Tissue Engineering, Institute for Frontier Medical Sciences, Kyoto \\ University, 53 Kawara-cho, Shogoin, Sakyo-ku, Kyoto 606-8507, Japan
}

(Received January 5, 2007)

\begin{abstract}
Drug delivery systems (DDS) have customarily been developed as part of the technology and methodology used to enhance the in vivo efficacy of therapeutic drugs. However, the DDS concept can also be used for prophylactic and diagnostic drugs to enhance their respective medical efficacy. When applied to biological signaling factors, such as growth factors and genes, which can regulate the proliferation and differentiation of cells, DDS are expected to realize cell-based tissue regeneration therapy. Basic research on biology and medicine which scientifically supports the advanced medical therapies currently available will be advanced by making use of DDS techniques. This paper overviews functional drug carriers indispensable for DDS which are part of the fundamental technology and methodology to achieve such advances.
\end{abstract}

Key words — - functional drug carriers; drug delivery systems; cell-based tissue regeneration; tissue engineering; advanced medical therapy; basic research

\section{1. ドラッグデリバリーシステム（DDS）概念の} 変遷

ある生物活性を持つ物質を体内に投入，その活性 によって病気を治すのが薬物治療である。これらの 物質はその目的から治療薬と呼ばれる.ところが, この治療薬の体内での動き, 運命を考えてみると, その作用部位への到達性の点からは, かならずしも うまく制御されているとはいえない。体内に入った 治療薬は，その作用部位及び作用細胞に届かなけれ ば，その効果は発揮されない。作用部位に届かなか つた場合には, 治療効果が望めないだけではなく, しばしば正常部位に対して毒性を示し，副作用の原 因となる，そこで，治療薬をその作用部位へ効率よ く運び，その治療効果を最大限に高める工夫が必要 となる，そこで, 治療薬の体内動態, 運命をコント ロールする目的で, 高分子, セラミックス，金属な ぞの様々な材料がデザインされ，それらと治療薬と

京都大学再生医科学研究所生体組織工学研究部門生体 材料学分野（干606-8507 京都市左京区聖護院川原町 53)

e-mail: yasuhiko@frontier.kyoto-u.ac.jp

本総説は, 日本薬学会第 126 年会シンポジウム S2 で発 表したものを中心に記述したものである.
の組み合わせ技術，方法論としてのドラッグデリバ リーシステム（DDS）が発展してきた。このよう に, これまでの研究開発の発展の経緯から, DDS の対象は治療薬であり，薬学の製剤学の 1 つである と考えられてきた.

DDS 技術，方法論は，このように薬物治療のみ に限定されるものであろうか. 病気の診断, 予防に 利用できる物質，すなわち診断薬，予防薬にDDS を適用すれば，診断，予防効果は高まるはずであ る。あるいは，DDS 概念をUV 吸収，美白物質に 適用すれば，これらの生物効果は高められ，スキン ケア，化粧分野にもよい効果を与える。新規な遺伝 子がみつけられ，それらの生物活性を調べたいと き，その遺伝子を細胞内に取り込ませ，核までデリ バリーさせ，核内で遺伝子を発現させる技術が必要 となる。この目的のためにも DDS 技術，方法論は 利用できる。このように，DDSとは，生物活性を 期待する物質の効果を高めるための基盤概念であ り，その材料，技術，方法論が適用できる範囲は極 めて広い. Table 1 に, 現在, 考えられる DDS 概 念の適応可能な分野を示す。近年のゲノム科学, 生 物医学研究のめざましい進歩に伴い，利用できる物 
Table 1. Biodegradable Biomaterials Applicable for Cell Scaffold

\begin{tabular}{|c|c|c|c|c|}
\hline & & Abbreviation & Crystinity & Typical shape \\
\hline \multirow{11}{*}{$\begin{array}{l}\text { Synthetic poly- } \\
\text { mer }\end{array}$} & Poly (glycolide) & PGA & Crystal & Fiberics \\
\hline & Poly (L-lactide-co-glycolide) $(10: 90)$ & $\mathrm{P}(\mathrm{L}-\mathrm{LA} / \mathrm{GA})(10: 90)$ & Crystal & Fiberics \\
\hline & Poly (D,L-lactide-co-glycolide) $(50: 50)$ & $\mathrm{P}(\mathrm{D}, \mathrm{L}-\mathrm{LA} / \mathrm{GA})(50: 50)$ & Amorphous & Sponge, film \\
\hline & Poly (D,L-lactide-co-glycolide) $(85: 15)$ & $\mathrm{P}(\mathrm{D}, \mathrm{L}-\mathrm{LA} / \mathrm{GA})(85: 15)$ & Amorphous & Fiberics, sponge \\
\hline & Poly (glycolide-co- $\varepsilon$-caprolactone) $(75: 25)$ & $\mathrm{P}(\mathrm{GA} / \mathrm{CL})(75: 25)$ & Amorphous & Fiberics \\
\hline & Poly (L-lactide) & P-L-LA & Crystal & Fiberics \\
\hline & Poly（D,L-lactide） & P-D, L-LA & Amorphous & Sponge \\
\hline & Poly (L-lactide-co- $\varepsilon$-caprolactone) $(75: 25)$ & $\mathrm{P}(\mathrm{L}-\mathrm{LA} / \mathrm{CL})(75: 25)$ & Crystal & Fiberics \\
\hline & Poly (L-lactide-co- $\varepsilon$-caprolactone) $(50: 50)$ & $\mathrm{P}(\mathrm{L}-\mathrm{LA} / \mathrm{CL})(50: 50)$ & Amorphous & Sponge \\
\hline & Poly ( $\varepsilon$-caprolactone) & PCL & Crystal & Fiberics \\
\hline & Poly ( $\rho$-dioxanone) & PDS & Crystal & Fiberics \\
\hline \multirow[t]{4}{*}{ Natural polymer } & Collagen & & Crystal & Gel, sponge \\
\hline & Gelatin & & Amorphous & Gel, sponge \\
\hline & Fibrin & & Crystal & Gel, sponge \\
\hline & Polysaccharide & & Crystal & Gel, sponge \\
\hline \multirow{2}{*}{$\begin{array}{l}\text { Inorganic materi- } \\
\text { al }\end{array}$} & Tricalcium phosphate & TCP & Crystal & Porous substrate \\
\hline & Calcium carbonate & $\mathrm{CaCO}_{3}$ & Crystal & Porous substrate \\
\hline
\end{tabular}

質の種類も，低分子から高分子物質，ウイルス，細 菌，細胞に至るまで増え，これらを用いた新しい先 端医療（治療，予防，診断）の発展が期待されてい る。「ドラッグ＝生理活性を持つ物質」という言葉 の意味をより広く考えることが必要な時代となって いる.

\section{2. 先端医療の中での再生医療の位置付け}

移植肝臓の不足のために, 命を落としていく肝不 全の子供を目の前にして，米国の小児肝臓移植外科 医と材料工学者とがアイデアを出し合って, 肝細胞 を生体吸収性高分子からなる 3 次元スポンジ材料内 で培養, 得られた肝細胞の増殖塊を治療に利用でき ないかと考えた。これが再生医療の始まりである.

用いる細胞が患者由来のものであれば，得られた肝 臓様構造体に対する免疫拒絶反応もなく，かつ材料 が消失するため異物反応もなく, 理想的な治療法と なる．ここで大切な点は，この再生医療のアイデア を実現させるためには，細胞とその周辺環境を作る ための生体吸収性材料との両方が必要であることで ある. 近年の再生現象に係わる基礎生物医学研究の 進歩により, 生体組織や臓器中にも細胞分化能力の 高い幹細胞や前駆細胞の存在 ${ }^{1)}$ が明らかとなり，そ れらの利用も可能になってきた。また，増殖分化を 促し，生体組織の再生を誘導するためには，細胞の 局所周辺環境が不可欠であることも明らかになって
きている.このように，細胞の再生誘導を活用した 再生誘導治療（と一般には呼ばれている）再生医療 には，細胞とともに細胞が増殖，分化し易い場を設 定することが必要不可欠となる. ${ }^{2-5)}$ この生体組織 の再生誘導を手助けするための場を作り与える医工 学技術, 方法論が生体組織工学（Tissue Engineering）であり，多くの材料が，様々な目的で利用さ れている，細胞の増殖，分化を制御している細胞の 周辺環境は，タンパク質，多糖，脂質などからなる 細胞外マトリクス（天然の足場）と生体シグナル因 子と細胞の表面成分などから構成されている，再生 現象に係わる基礎生物医学（再生医学と呼ばれる） が発展し, 細胞の周辺環境の働きや再生のメカニズ ムが解明されることが大切であることは疑いない. しかしながら，それらの基礎的知見が直接には患者 の治療（つまり再生医療）につながらないことも多 い.この基礎生物医学である再生医学と前述した生

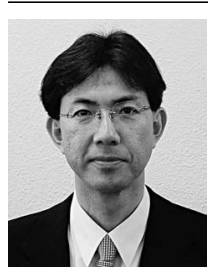

田畑泰彦
京都大学再生医科学研究所教授、大阪 大学大学院医学系研究科教授. 1959 年 大阪府生まれ。京都大学工学部高分子 化学専攻博士課程終了. 1981 年京都大 学医用高分子研究センター助手, 1996 年助教授, 2000 年教授, 現在に至る. 京大工博, 京大医博. 京大薬博. 米国 MIT, ハーバード大学医学部に留学. 生体材料, 生体組織工学, DDS の研究に従事. 抱負は生 命科学のわかる材料科学研究者の育成. 
体組織工学との両研究分野が車の両輪のごとく機能 して初めて, 再生誘導治療に再生医療が実現される ことを忘れてはいけない. 生体シグナル因子の生物 作用を発揮させ，かつ細胞の増殖，分化を促す性質 を持つ足場材料は，先端医療としての再生医療を支 える機能性薬物キャリアの代表例である.

再生誘導治療（=再生医療）は, 人工臟器, 免疫 抑制剂を用いない点で，再建外科，臓器移植などの 外科治療とは大きく異なるが，もちろん，長所短所 もあり，オールマイティではない。しかしながら， これまでの先端外科治療の欠点を補い，治療の適用 拡大を可能とするだけでなく，新しい治療法を提案 する可能性もあるため，患者に福音をもたらす第 3 の治療法としての位置を確立しつつある．再生医療 は患者自身の自然治癒力を介した再生誘導治療がそ の基本概念であり，患者に対してやさしい理想的な 治療法である。このアイデアは，これまでは，主に 外科治療と組み合わされて展開されてきた。しかし ながら, 再生誘導の概念は, 慢性疾患の再生治療, 組織の器質化促進による動脈瘤の血管内カテーテル 治療などにも生かされ，今後は，内科治療に対して も再生誘導治療は重要な役割を演じていくと考えら れる. ${ }^{4-6)}$

\section{3. 再生誘導治療のための生体吸収性材料と生体} 組織工学

生体組織の再生誘導による修復と臓器機能の代替 による疾病の治療が行われる場所により，生体組織 工学は生体外と生体内とに分けられる. 生体外アプ ローチでは，再生誘導の場の設定に大きな工夫が必 要となり，これまでの基礎生物医学知識と細胞培養 技術のみでは限界がある。これに対して，生体内で は，再生誘導に必要な物質が自動的に供給される可 能性がある，再生医療の目的は，患者の病気を治療 することであり, 現時点では，その実現性の高いこ とから，ほとんどすべての生体組織の再生誘導治療 は生体内アプローチによって試みられている. ${ }^{2-6)}$

その基本的な戦略は, 細胞, 細胞外マトリクス, 及び細胞増殖因子の生体組織の 3 要素を組み合わせ て生体組織・臓器の再生を誘導することである。再 生誘導させたい部位によって，その組み合わせパ ターンは変化するが，そのいずれの場合にも生体吸 収性高分子材料が重要な役割を果たしている.

現在の医療現場では，高分子，金属，セラミク
ス，それらの複合材料，あるいは生体由来材料など の多くの生体材料が使われている. ${ }^{7)}$ そのほとんど は生体非吸収性であるが，生体吸収性材料も用いら れている。これらの吸収性材料は，いずれ，体内か ら消失してしまうため, 非吸収性材料に比較して, その生体適合性を考慮する必要性は少ない。また, 分解物に細胞毒性がなければ，生体安全性の問題も ない。ハイドロキシアパタイト及び免疫隔離膜など を除いて，足場材料，DDS 材料などの目的で，生 体組織工学に利用されている生体材料のほとんどが 生体吸収性材料であるため, ここでは簡単に説明を 加える，生体吸収性とは，酵素的であれ非酵素的で あれ，生体内で材料の重量が減少して最終的には材 料が消滅してしまうことである，現在，生体安全な 生体吸収性の金属材料, リン酸三カルシウムと炭酸 カルシウム以外の生体吸収性のセラミックス材料は 存在しないため, 今日，生体吸収性材料として臨床 応用されたり，研究されているのは，ほとんどが高 分子材料である. Table 1 には，現在，スキャホー ルドとして臨床応用あるいは研究中の生体吸収性材 料の種類とその性質を示す．Figure 1 は高分子材料 の化学構造を示す. 合成高分子は加水分解あるいは 酸加水分解によって，合成ペプチドと天然高分子は 加水分解酵素によって分子鎖が切断され，材料が体 内で消滅する.

生体組織工学における生体材料の第 1 の役割は生 体組織再生のための足場である。 ${ }^{3,8-10)}$ 生体内で は，血液細胞を除くほとんどすべての細胞は細胞外 マトリクス（足場）に付着して存在している．例え ば，このマトリクスまでもなくなっている場合に は，細胞を欠損部に加えるだけでは不十分で，Fig. 2(A)のように，人工的な足場材料を欠損部に与え なければ欠損部位における組織の再生は誘導されな い. 細胞を立体的に配置させ，その接着・増殖・分 化促進のための適当な人工細胞外マトリクスが必要 である. ${ }^{11)}$ 足場に要求される性質は，生体吸収性， 多孔性，及び細胞親和性である。足場の生体吸収性 速度が遅いと, 足場の残存が組織の再生課程を物理 的に邪魔する。また，早い場合には，細胞の増殖， 分化を促すという足場としての役割が果たせない. 生体組織の再生誘導のための適切な生体吸収を持つ ことが必要である．細胞の侵入，あるいは足場内に 存在する細胞への酵素，栄養の供給，及び細胞の老 

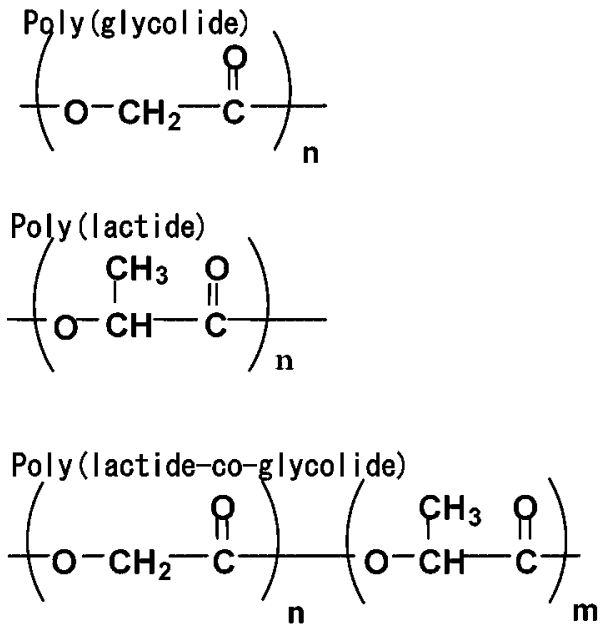

Poly (glycolide-co- - -caprolactone)
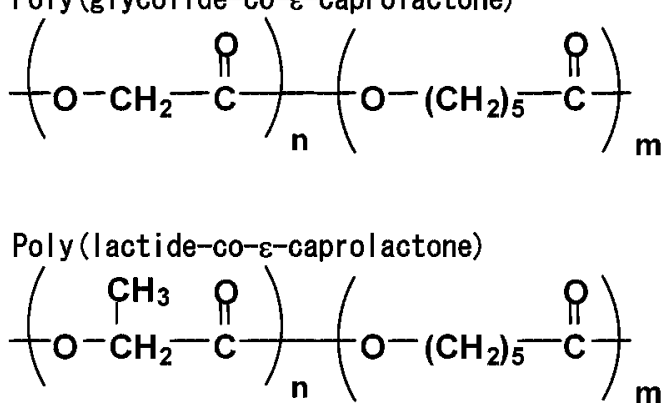
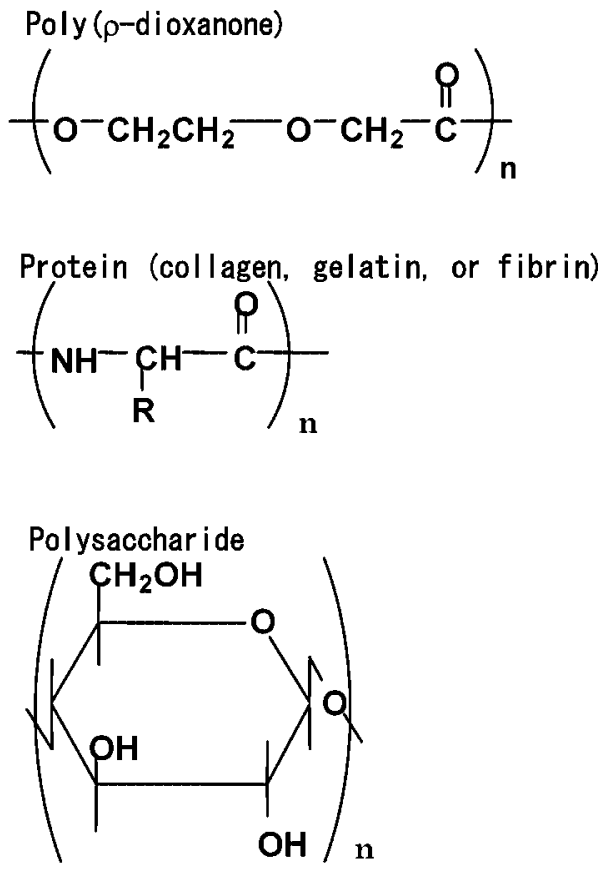

Fig. 1. Chemical Structure of Biodegradable Polymer

廃物の除去のために，足場は適度な多孔性を持つ必 要がある．細胞への親和性が必要なことは当然であ る。また，ハイブリッド人工臓器による臟器代替の 場合にも，機能細胞を高密度に充填，その生物機能 を維持するために細胞を適切な足場材料とともに利 用することが必要である。 今後，再生医学の進歩に より再生誘導のための生体シグナル因子, 細胞外マ トリクス成分が同定され，利用できるようになるで あろう。このとき，これらの因子，成分を薬物と考 え，これらの薬物を含んだ機能性キャリア足場がデ ザインされ，より効率のよい生体組織の再生誘導が 可能となっていくであろう. ${ }^{12)}$

2 番目の役割は, 宿主側からのタンパク質や細胞 の侵入を阻止するための隔離である。例えば，生体 内の大きな欠損部は，応急的な生体本来の創傷治癒 反応として, 線維性組織で充填されることがほとん ぞである，一度，このようになってしまうと，その 部位における望む生体組織の再生誘導は不可能とな る.この組織充填を防止するために再生誘導の場を 確保するための隔離膜が必要となる (Fig. 2(B)).
組織欠損部を生体吸収性膜で包夕，線維芽細胞の侵 入と線維性組織の形成を防ぎ，欠損部での再生誘導 を促す. Figure 2(A) で示した足場材料がこの隔離 能を兼ねている場合もある。 ハイブリッド人工藏器 で利用されている免疫隔離膜は，体内に移植された 肝臓，膵臓，細胞を抗体，免疫細胞の攻撃から守る 役割を果たし，再生誘導というよりも臓器機能の代 替効果を高める目的である.

生体外での生体組織工学では，細胞を足場材料に 播種し, 細胞培養によって細胞を増殖・分化させ, 生体組織様構造物を作る（Fig. 2(C))。これを生体 組織の欠損部へ埋入して組織再生を行う（Fig. 2 (A))。この目的のためにも，前述した生体シグナ ル因子を含んだ機能性薬物キャリア足場が必要とな る.このキャリアシステムによって，より生体に近 い組織様構造体を in vitro で作製することができる であろう。また，再生医療には，質のよい多数の幹 細胞が必要となるため，細胞を単離，増殖させるた めの培養技術及び培養装置（バイオリアクター）の 研究開発が必要である。例えば，単なる培養シャー 




(A) Biomaterials and technology for cell scaffold to induce the in vivo regeneration of tissues and organs. The scaffold is combined to use with cells and/or growth factors depending on the site to be regenerated.

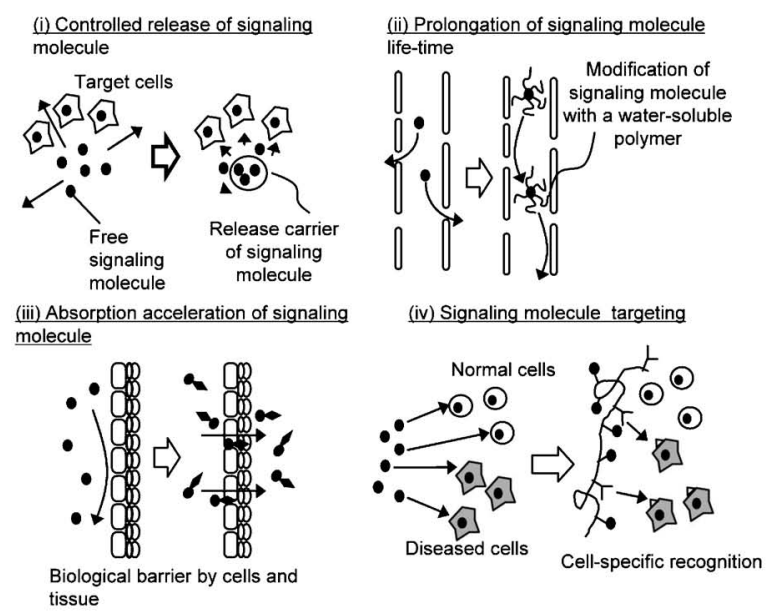

(B) Biomaterials and technology for DDS of biological signaling molecules (growth factors and the gene).



(C) Biomaterials and technology for cell culture to obtain cells clinically available.

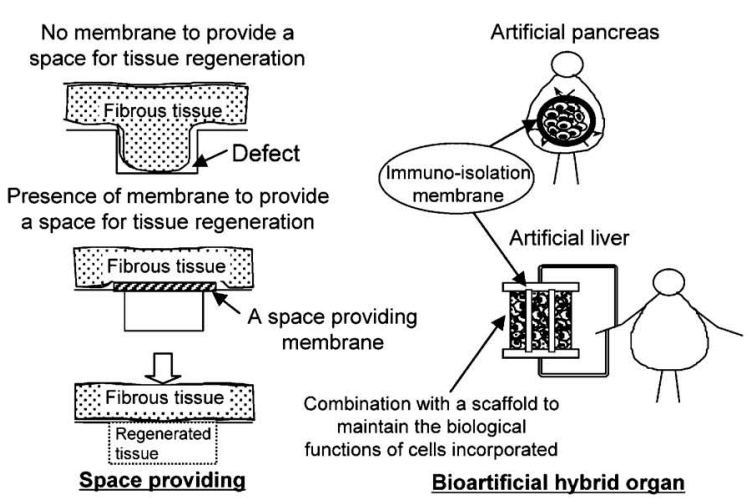

(D) Biomaterials and technology to protect a space for in vivo regeneration induction of tissue and organs.

Fig. 2. Role of Biomaterials in Tissue Engineering

レではなく, 生体内環境を模倣した機能性薬物キャ リア足場材料があれば，幹細胞の分離・増殖効率は 高まるであろう。

いかに優れた足場材料あるいは隔離膜があったと しても, 再生部位に必要な細胞の数が少なかった り, 細胞を増殖分化させる生体シグナル因子の濃度 が低すぎたりすれば，望む生体組織の再生誘導は期 待できない. そこで, 次に用いるべきものが細胞あ るいは細胞増殖因子である. 前述のように, 得られ る細胞の質と数の問題が解決すれば，その細胞を利 用することができる。生体シグナル因子を用いるた めにも技術が必要である。一般に, 細胞増殖因子の 生体内寿命は短く不安定であり, 必要な因子を, 単 に水に溶かして必要部位に投与するだけでは，期待 する組織再生促進効果は得られない。そこで，再生 の場において細胞増殖因子の濃度を必要な期間に渡 つて有効值に保たなければならない。これを可能に する技術が DDS である，例えば，細胞増殖因子を
再生の場で持続的に放出（徐放）させることができ れば，細胞の増殖分化が高まり，自己組織の再生が 促される。生体吸収性の生体材料はこの徐放キャリ アの役割を果たす (Fig. 2(D) ). ${ }^{3,10,13)}$ 徐放化システ ムは単独あるいは細胞とともに足場材料と組み合わ せて生体組織の再生誘導に用いられる（Fig. 2 (A))。前述したように, 体内の細胞外マトリクス を模倣するような徐放化能を持つ足場としての機能 性薬物キャリアのデザインと作製が強く望まれてい る.

\section{4. 再生誘導治療における DDS の重要性}

基礎生物医学の進歩によって，優れた細胞増殖因 子, 遺伝子がみつけられ, 利用できるようになつた としても，それらの生物効果を生体内で発揮させる ことができなければ，再生誘導治療は実現できな い.これを可能とさせるための投与剤形の工夫，す なわち DDS が必要となる。薬物を必要な部位のみ に必要な量だけ必要なときに送り込むための技術方 
法論であるDDS の目的には，薬物の徐放化，薬物 の生体内寿命の延長，薬物の吸収促進，あるいは薬 物のターゲティングなどがある (Fig. 2(D)) . DDS は，これまでの研究開発の経緯から，薬物治療のイ メージが強く，再生医療とは無関係であると考えら れてきたが，生体内で不安定で，しかも作用部位の 特異性もない細胞増殖因子，遺伝子などを利用する 限り，DDS 技術は不可欠である. ${ }^{14)}$ DDS のいずれ の目的も再生医療のためには有用である。生体シグ ナル因子の安定化を向上，体内寿命を延長させた り，その作用部位へのターゲティングが可能となれ ば，因子の生物作用を介した生体組織の再生誘導は 大いに期待できる。.また，分子量の大きな因子の作 用発現には吸収促進技術は不可欠である。ここでは 最も実用化に近い薬物の徐放化を利用した再生誘導 治療についての話を中心に進める.

再生誘導治療で用いる薬物は細胞増殖因子及びそ の遺伝子である，既に，生体組織の再生を目指した 細胞増殖因子の利用が試みられ，その徐放化が必要 不可欠であることが強調されている. ${ }^{15)}$ タンパク質 の徐放化における最大の問題は生物活性の低下であ り，単に細胞増殖因子と徐放キャリア材料とを混ぜ るだけでは，この問題点を解決することは極めて難 しい，例えば，グリコール酸・乳酸系高分子を用い てタンパク質薬物を徐放しようという試みが行われ ているが，水不溶性の徐放担体高分子と水溶性の薬 物とを均一に混合するための種々のプロセスが必要 となる．このプロセスによって，多くの場合には夕 ンパク質を変性，その生物活性を低下してしまう. タンパク質の変性を抑制する 1 つの方法として, 夕 ンパク質と同じ水溶性で，しかも生体吸収性の高分 子からハイドロゲルを作製し，それを徐放キャリア として利用することが考えられている。これまでに も，高分子ハイドロゲルを用いたタンパク質の徐放 化の研究は行われている. ${ }^{16)}$ しかしながら，これら の徐放システムでは，ハイドロゲル内の水相中での タンパク質の拡散速度によってその徐放速度を制御 している，そのため，ハイドロゲルの架橋密度をい かに高めても，タンパク質の拡散を抑制できる期間 に限界があり，この方法論では 3,4 日間以上の夕 ンパク質の徐放化は不可能である。ましてや体積当 たりの表面積の大きな粒子状ハイドロゲルからの夕 ンパク質の徐放化は，事実上，不可能となる。さ
に，タンパク質が徐放したのちにもハイドロゲルが 残存するため，このハイドロゲルキャリアの残存が 生体組織再生を物理的に邪魔することになり，再生 誘導治療のための機能性薬物キャリアとしては利用 できない。そこで，別の徐放メカニズムを持つ薬物 キャリアを創製する必要がある。そこで，われわれ は，徐放キャリアの分解に伴う薬物の徐放システム を考案した。 ${ }^{17)}$ 例えば，徐放したい細胞増殖因子と 相互作用する性質を持つ生体吸収性高分子からハイ ドロゲルを作製する。つまり，細胞増殖因子をハイ ドロゲル高分子と物理化学的に相互作用させること によって，因子をハイドロゲル内に物理的に固定化 する．この相互作用力は十分に強く，酵素などによ りハイドロゲル高分子鎖が分解，水可溶化されなけ れば，固定化された細胞増殖因子はハイドロゲルか らは放出されない。つまり，この徐放化システムで は，徐放キャリアであるハイドロゲルの分解に伴う ハイドロゲル高分子の水可溶化によってのみ細胞増 殖因子は徐放化される．生体内における細胞増殖因 子の生物活性の発現メカニズムは次の 2 つが知られ ている. 1 つ目は，細胞から分泌された細胞増殖因 子が直接に自分あるいはほかの細胞に作用し，その 生物活性を発揮する。もう 1 つは，細胞から分泌さ れた因子は細胞外マトリクスに物理化学的相互作用 力によって固定化，保存されている.この固定化細 胞増殖因子は, 細胞から分泌される酵素によるマト リクスの分解，水可溶化に伴い，必要に応じてマト リックスから徐放される。徐放キャリアの分解に伴 うタンパク質の徐放ハイドロゲルシステムは，この 後者の天然の徐放システムを模倣したものである (Fig. 3). 3,13)

一般に, 細胞増殖因子は塩基性タンパク質が多 く，その分子表面に正電荷に富む領域が存在してい る. ${ }^{18)}$ そこで，タンパク質と徐放化キャリア高分子 との間の静電的相互作用力を利用した徐放システム が考えられる。キャリア高分子としては，電荷を持 ち，生体吸収性で，なおかつ生体安全性のものであ ることが望ましく，この目的に利用できるのはタン パク質あるいは多糖などである，われわれはキャリ ア高分子として，化学修飾が容易であり，また，こ れまで医学, 薬学, 食品分野で長く使用され, その 生体安全性は保障されたゼラチンを利用することを 考えた。ささらに，コラーゲンからの処理抽出法によ 
(A)

Biodegradable polymer (carrier matrix)

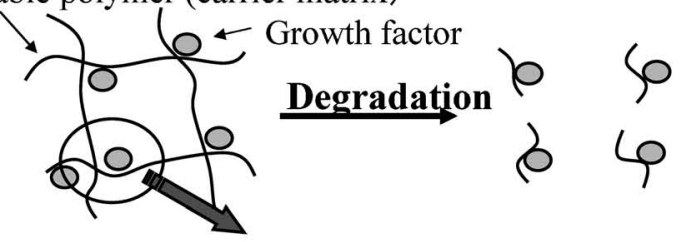

\section{Possible intermolecular interaction between carrier matrix and growth factor

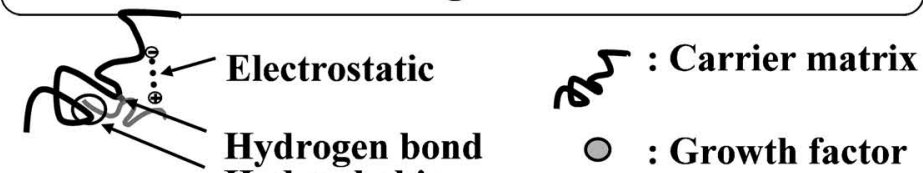 \\ Hydrophobic}

(B)
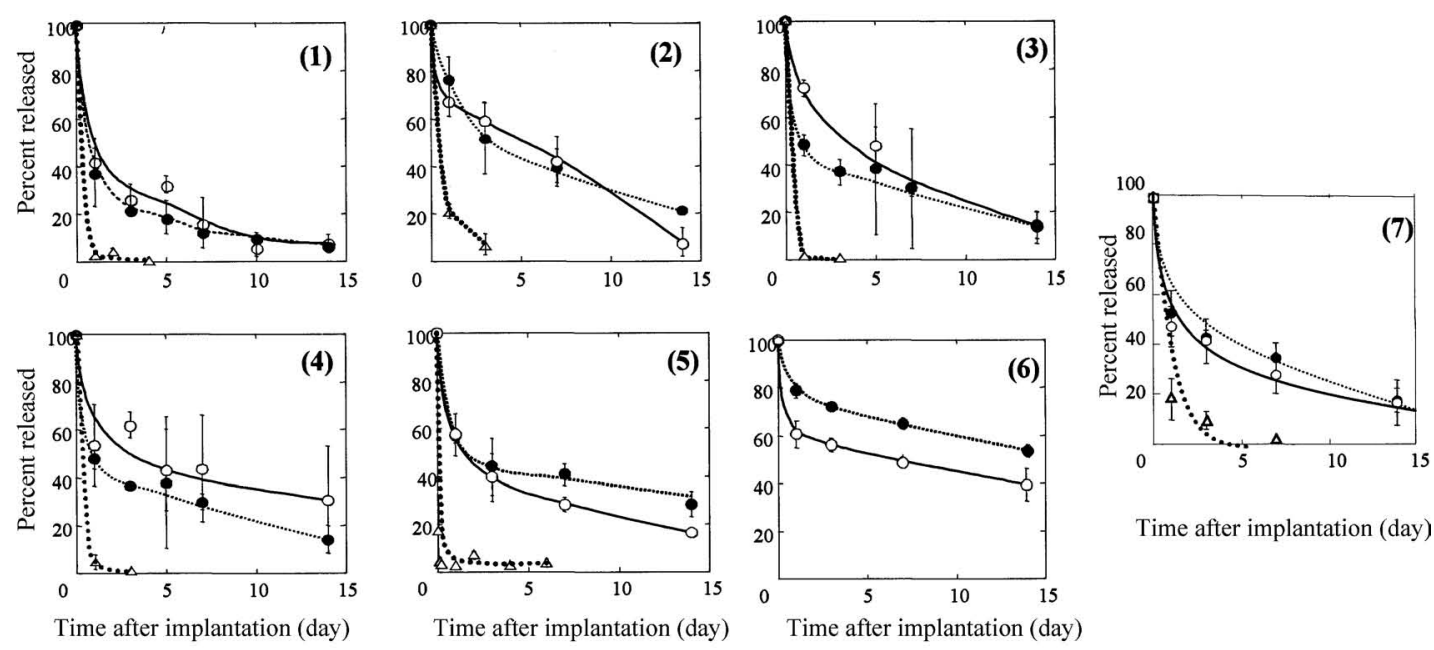

Time after implantation (day)

Time after implantation (day)

$\mathrm{O}$ : in the hydrogel-incorporated form

: hydrogel degradation $\triangle:$ in the solution form

(1)transforming growth factor $\beta 1$ (TGF- $\beta 1$ ), (2)basic fibroblast growth factor (bFGF), (3)hepatocyte growth factor (HGF) (4)platelet-derived growth factor BB (PDGF-BB) (5)bone morphogenetic protein 2 (BMP-2) (6) epidermal growth factor (EGF) (7) plasmid DNA

Fig. 3. (A) Mechanism on the Controlled Release of Growth Factor with Biodegradable Hydrogel and (B) In vivo Release Profiles of Growth Factors and Plasmid DNA from Biodegradable Hydrogel of Various Gelatins

り，その物理化学的性質が変わり，性質の異なる材 料の入手が可能であるなどの特徴を持つ。例えば, アルカリ処理によって，グルタミン，アスパラギン などの側鎖の酸アミドが加水分解され，カルボキシ ル基となり，等電点が 5.0 である “酸性”タイプの ゼラチンが得られる.この酸性ゼラチンは塩基性夕 ンパク質である塩基性線維芽細胞増殖因子（bFGF） と，予想通り，主として静電気的に相互作用するこ と，また，この相互作用力を利用して，bFGF を酸
性ゼラチンハイドロゲル内に固定化できること，さ らに，ハイドロゲルの分解によって徐放化できるこ


ゲル作製時におけるグルタルアルデヒド濃度を変化 させることで, ゼラチンの化学架橋の程度を変える ことができ，異なる生体吸収性を持つハイドロゲル の作製ができる，例えば， ${ }^{125}$ I でラベルしたゼラチ ンハイドロゲルをマウス背部皮下に埋入したとこ ろ，残存放射活性は時間とともに減少した，架橋反 
応条件によってハイドロゲルの生体内吸収性をコン トロールできた（Fig. 4(A))。同じゼラチンハイド ロゲルに ${ }^{125} \mathrm{I}$ ラベルした bFGF を含浸させ，同様に マウス皮下での残存放射活性をみたところ， bFGF の残存量も時間とともに減少し（Fig. 4(B)), 生体 内でのハイドロゲルと bFGF の残存性の間には高 い相関性が認められた（Fig. 4 (C))。この結果は, Fig. $3(\mathrm{~A})$ に示したように，徐放キャリアであるハ イドロゲルの分解とともに bFGFが徐放化してい ることを示している。 このハイドロゲルシステムで は，bFGF の徐放はハイドロゲルキャリアの分解挙 動にのみ依存することから，徐放キャリアの形状に 影響されない. その結果，前述したように，従来ま での技術では不可能であった粒子状キャリアからの
bFGF の徐放化が可能となつた. ${ }^{3)}$ 加えて，ゼラチ ンとの相互作用による bFGF の酵素消化に対する 抵抗性も向上することが分かっている.19)この生体 吸収性ハイドロゲルを用いることで, bFGF 以外の 細胞増殖因子あるいはプラスミド DNA をハイドロ ゲルキャリアの分解とともに徐放化することができ ることが分かってきている（Fig. 3(B))．加えて， この徐放システムを利用した small inference RNA （siRNA）生物効果を増強させ，その治療効果を高 めることも可能になっている. ${ }^{22)}$

\section{DDS 技術を用いた再生誘導治療の実際}

前述した生体吸収性ハイドロゲルキャリアを用い て，生物活性を持つ細胞増殖因子を再生の場で持続 的に放出（徐放）させることにより，種々の生体組
(A)

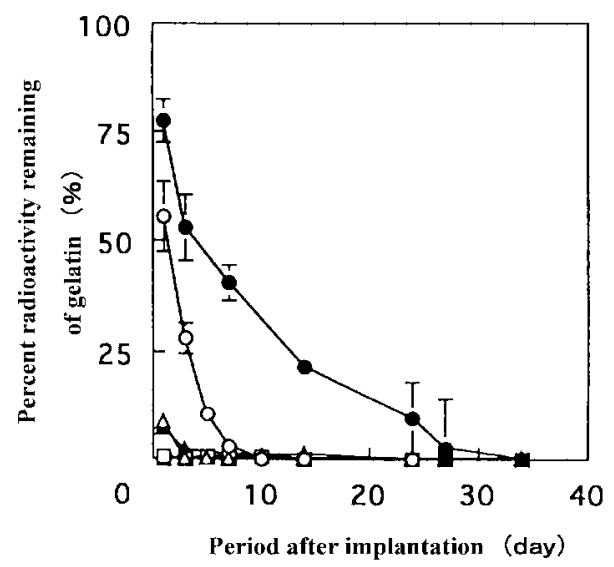

(C)

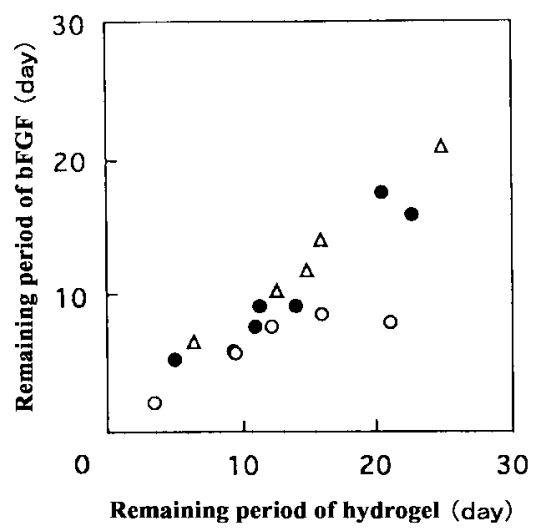

(B)

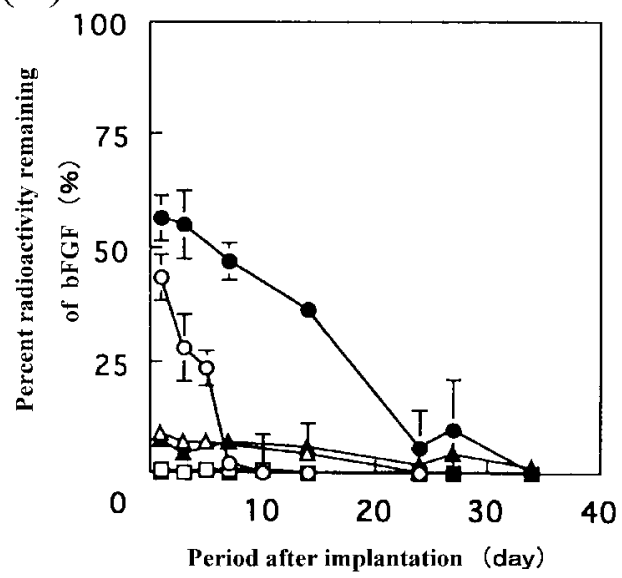

Fig. 4. (A) The Time Course of the Radioactivity Remaining of ${ }^{125}$ I-labeled Gelatin Hydrogels with Water Contents of 98.8 (open maker) and 96.9\% (closed marker) after Implantation into the Back Subcutis of Mice, (B) The Time Course of the Radioactivity Remaining of ${ }^{125}$ I-labeled bFGF-incorporating Gelatin Hydrogels with Water Contents of 98.8 (open maker) and 96.9\% (closed marker) after Implantation into the Back Subcutis of Mice, and (C) Relationship of the Radioactivity Remaining between the Gelatin Hydrogel Incorporating ${ }^{125}$ I-labeled bFGF and ${ }^{125}$ I-labeled Hydrogel

$\bigcirc$, : in hydrogels, $\triangle, \boldsymbol{\Delta}$ : around hydrogels, $\square, \mathbf{\square}$ : in the blood. Percent remaining of gelatin hydrogel or bFGF is $(\bigcirc) 80$, $50,(\triangle) 20 \%$ 
織の再生誘導が可能となっている (Table 1). 2,3,14) その具体例を Figs. 5, 6 and 7 に示す．その中の虚血 性疾患に対する血管新生誘導治療及び胸骨と胸骨周 辺軟組織の再生治癒促進治療については, 既に大型 動物実験も終了し，病院の倫理委員会の許可も得ら れている，既に，下肢虚血疾患に対する血管申請治 療の臨床試験が始まり，よい治療成績が得られ，前 述したように，再生誘導治療の概念は内科的治療に も活用されている. ${ }^{23)}$ 例えば， bFGF 含浸ハイドロ ゲルをコーティングしたコイルを用いた脳動脈瘤の カテーテル内科治療も始まっている. ${ }^{24)} \mathrm{bFGF}$ を瘤 内で徐放化することにより組織の器質化促進が得ら れ，再生誘導カテーテル治療が可能になってい る. ${ }^{25)}$

近年，遺伝子による生体組織の再生誘導も試みら れている.アデノウイルスベクターを用いた難治性 循環器疾患に対する遺伝子治療が行われているが, ウイルスに由来する抗原性，毒性の問題を避けるこ とができない。そこで，プラスミド DNA を用いた 血管新生治療法の臨床試験，骨再生の実験的試みが 行われている。しかしながら，その遺伝子発現がウ イルスベクターに比べて極めて低く，発現レベルを 高める工夫が必要となる。DDS 技術を用いた種々 の非ウイルスキャリアの研究開発が進められている 中で, ${ }^{26)}$ プラスミド DNA の徐放化（Fig. 3(B)）が DNA の発現効率を高められることが分かってきて いる. ${ }^{27)}$ 遺伝子治療に加えて，今後は，遺伝子によ り改変，増強された幹細胞を用いた細胞移植再生治 療も行われるであろう。ウイルスベクターを用いた 遺伝子改変細胞は臨床応用へのバリアが高く，遺伝 子改変のための強力な非ウイルスベクターの開発が 必要となる。例えば，カチオン性ゼラチン微粒子を 利用してプラスミド DNA を幹細胞内に取り込ま せ，細胞内で徐放化する．この技術によって， ウイ ルスベクターに匹敵する遺伝子発現が達成され，ま た, その遺伝子改変幹細胞は元の幹細胞に比較し て，その細胞移植治療効果が有意に増強されること が分かっている. ${ }^{28)}$ 加えて，プラスミド DNA のカ チオン化多糖，細胞接着因子をコーティングした基 材上で細胞を培養，遺伝子導入を行う（リバースト ランスフェクション法) により, 細胞毒性の低い, かつ発現レベルの高い遺伝子導入が可能になってい る. ${ }^{29)}$
また，生体内の欠損部に外科的に再生の場を作り 再生を誘導する「外科的再生」のアプローチとは異 なり，難治性慢性疾患の治療を行うという「内科的 再生誘導治療」の試みも始まっている。「内科的再 生」では，DDS の技術を活用した内科的薬物治療 によって, 線維化組織を消化分解し, 周辺組織の再 生誘導能力によって患者本来の組織を病的なものか ら再生可能な組織へと是正し, 組織再生修復を行 う。体本来の持つ再生誘導能力を活用する点におい て,「外科的」と「内科的」との両者の治療概念は 共通している，例えば，糖尿病性腎症モデルマウス の腎皮膜下で線維性コラーゲンを分解するマトリッ クスメタロプロテアーゼ（MMP）のプラスミド DNA を徐放化したところ，生化学的にも組織学的

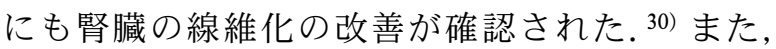
HGF を徐放することによる拡張型心筋症や肝硬 変31)の進行の抑制も報告されている.

\section{6. おわりに}

$\lceil\mathrm{drug} 」$ とうう言葉の意味を英英辞典で調べてみ ると,「Substance taken for the effects it produces」 と記載されている。これからも分かるように, 「drug」とは, 特に, 薬物治療を目指した物質に限 定されている訳ではない。つまり，DDS とは，投 与（送達）方法や形態を工夫し， drug の動きを精 密にコントロールすることによって，その作用発現 部位に望ましい濃度-時間パターンの基にdrug を 選択的に送り込み, 結果として, 最高の生物効果を 得ることを目的とした drug の投与（宅配）に関す る概念であると広く理解することができる。つま り, これまでの基礎, 応用研究の発展の経緯から, 薬物治療のための技術，方法論であると考えられて きた DDS が，実は，基礎生物医学あるいはその関 連応用分野，さらには薬物治療以外の治療，予防， 診断の開発研究にも必要不可欠な基盤テクノロジー である。これまでの DDS=薬物治療という固定の 既存概念に捉われず，体外，体内に関係なく，不安 定かつ作用部位の特異性もないdrug（物質）にな んらかの生物医学効果を期待するためには，使われ る物質の動きと運命の制御が大切である。これを行 うための技術・方法論が DDS であると考えれば, DDS が生物医学研究と医療の基盤テクノロジーで あることが理解して頂けたであろう。

現在の医療は生物医学だけではなく, 多くの研究 
(A)

(a)
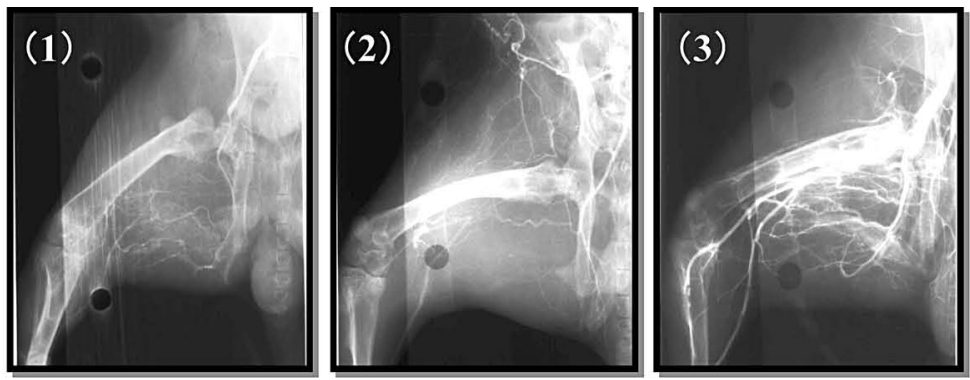

(b)

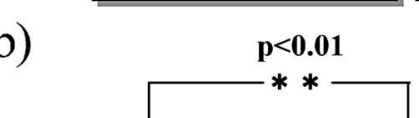

N.S.



$\hat{e}^{(c)}$

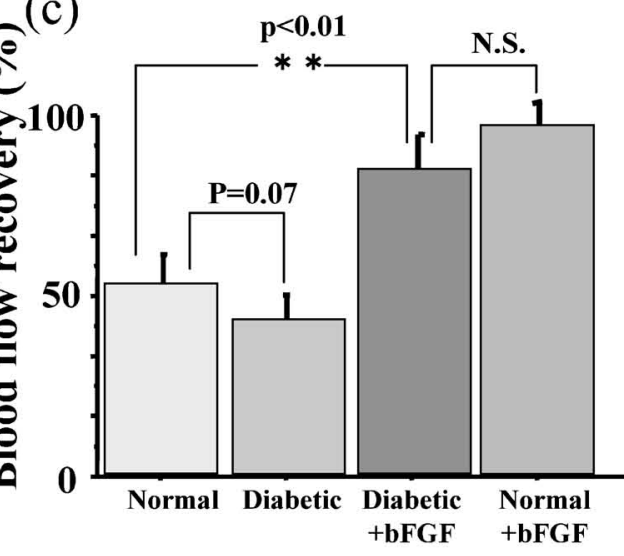

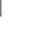

(B)

(a)

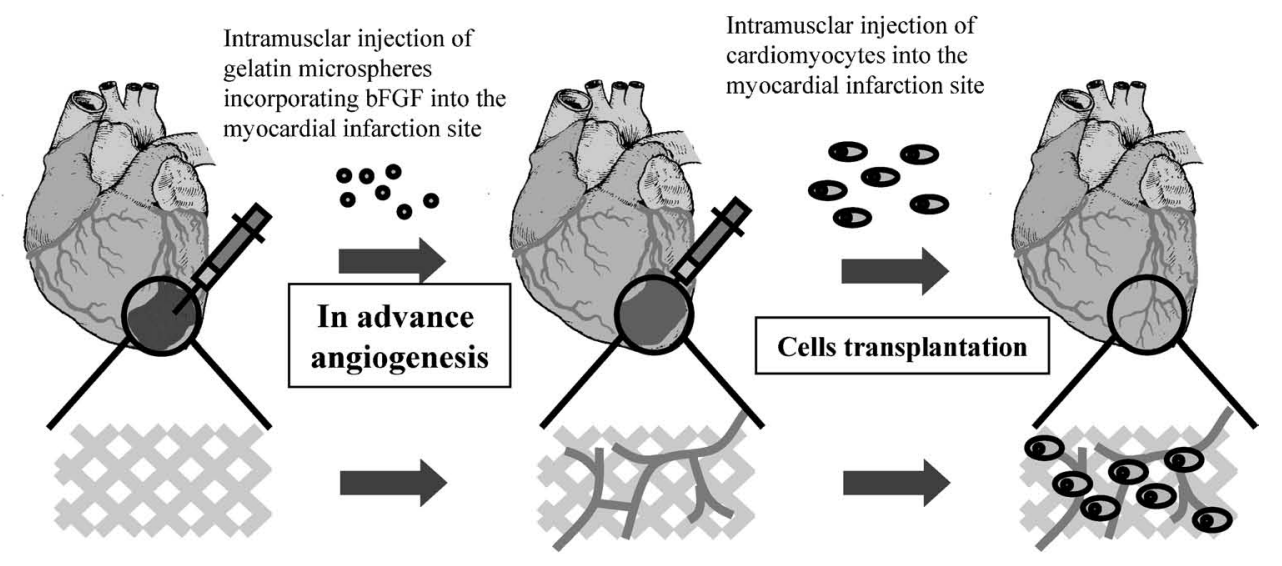

(b)

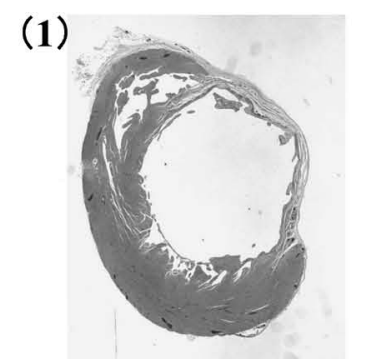

(2)

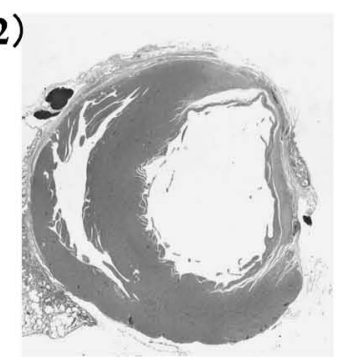

(3)

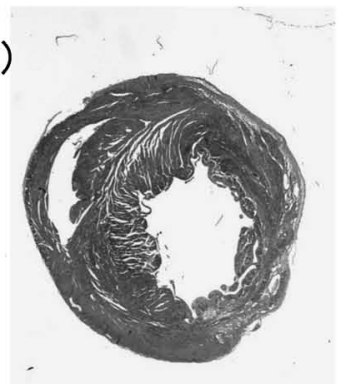

Fig. 5. Angiogenic and Cell Transplantation Therapies by the Controlled Release Technology of bFGF from Gelatin Hydrogels

(A) (a) Angiograms of ischemic area of rats hind-limb 4 weeks after ligation of the femoral artery and its branches of streptozotocin-induced diabetic rats. No treatment (1) or free basic fibroblast growth factor (bFGF) (2) and gelatin microspheres incorporating bFGF (3) were injected into the ischemic muscle 1 week after ligation. The density of blood vessels newly formed (b) and the percentage of laser doppler perfusion imaging (LDPI) index (blood flow) (c) of normal and diabetic rats before and after treatment with gelatin microspheres incorporating bFGF. The bFGF dose is $100 \mu \mathrm{g} / \mathrm{muscle}$. The hydrogel incorporating bFGF significantly enhanced efficacy in angiogenic therapy. (B) A therapeutic trial of chronic myocardial infarction by the combination of cardiomyocytes transplantation with in advance angiogenesis by the controlled release technology of bFGF from gelatin hydrogels. (a) Schematic diagrams of myocardial infarction therapy in advance angiogenesis by gelatin microspheres containing bFGF, followed by cardiomyocytes transplantation. (b) Cross-sections of ischemic dog hearts 4 weeks after application: (1) no treatment (2) cardiomyocytes transplantation, and (3) combination of cardiomyocytes transplantation with in advance bFGF-induced angiogenesis. The bFGF dose is $100 \mu \mathrm{g} /$ heart. The hydrogel incorporating bFGF significantly enhanced efficacy in cell therapy. (Hematoxylin and eosin staining, original magnification $1 \times$.). 


\section{(A)}

(a)

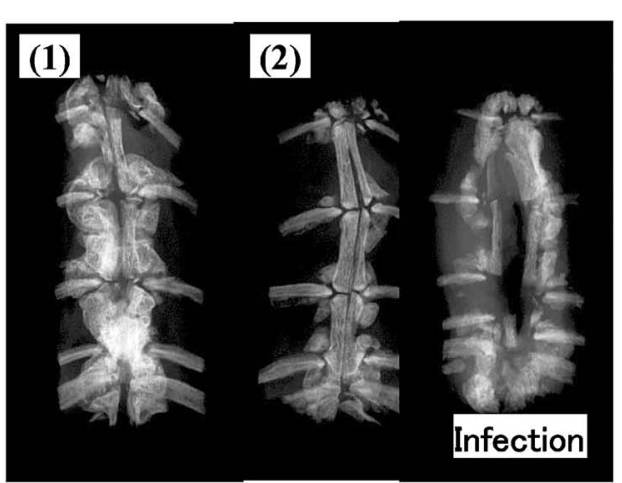

(B)

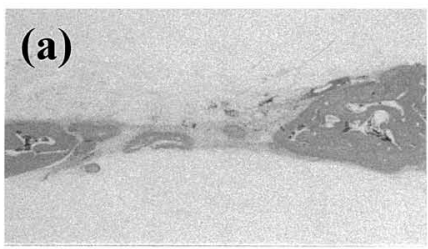

(c)

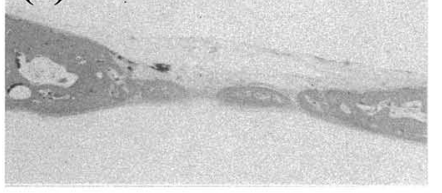

(e)

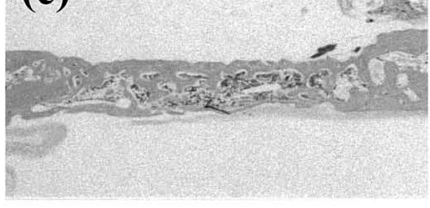

(b)

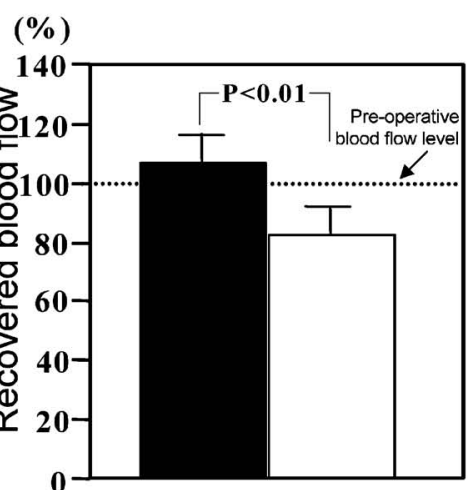

(1)

(2)

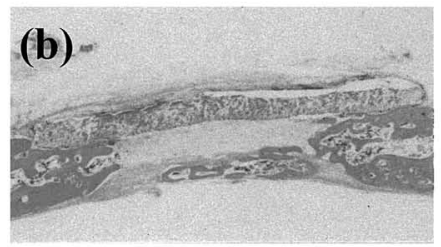

(d)

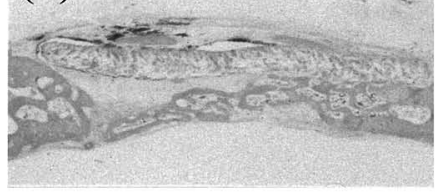

(f)

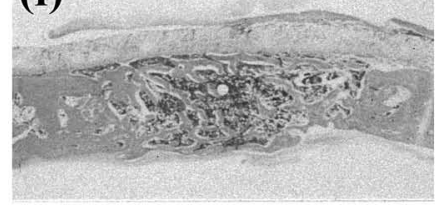

Fig. 6. Bone Regenerative Therapy by the Controlled Release Technology of Growth Factors from Gelatin Hydrogels with or without a Barrier Membrane to Make a Space for Tissue Regeneration

(A) (a) Sternum regeneration 4 weeks after application of gelatin hydrogels incorporating $100 \mu \mathrm{g}$ of bFGF (1) and bFGF-free PBS (2) to the sternum defect of diabetic rats. (b) Recovery of blood flow at the soft connective tissue around the sternum 4 weeks after application of gelatin hydrogels incorporating $100 \mu \mathrm{g}$ of bFGF (1) and bFGF-free PBS (2). The hydrogel incorporating bFGF significantly induced the bone regeneration at the resection area of sternum and angiogenesis at the soft connective tissue around the sternum, resulting in accelerated tissue regeneration and repairing. (B) Histological sections of rabbit skull defects 6 weeks after application with PBS (a, b), free TGF- $\beta 1$ (c, d), and gelatin microspheres incorporating $0.1 \mu \mathrm{g}$ of TGF- $\beta 1$ (e, f). Each defect was coverd with (b, d, f) or without $(\mathrm{a}, \mathrm{c}, \mathrm{e})$ a barrier membrane. Bone regeneration was significantly induced by the combination of the hydrogels incorporating TGF- $\beta 1$ and the barrier membrane.

領域の研究成果の上になり立っていることは言うま でもない，治療学の 1 つである再生誘導治療（=医 療）も同じである。再生誘導治療の目的は，新しい 治療法の確立であり, 発生・分化の解明ではない. 生物学としての発生・分化の解明も重要であるが, 今日の疾病の治療は病因の解明をまって行われるの ではなく，むしろそのような例はわずかである，本 稿を読んでいただいた読者の皆様には，ごく少しの
組織を除いては，その再生誘導に細胞だけではなく DDS を中心した生体組織工学が必要不可欠であ ることが分かって頂けたと信じている．薬学分野の 貢献が今後の生体組織工学の発展を左右するといつ ても過言ではなく, 再生誘導治療への薬学的アプ ローチとDDS の新しい概念について今一度考えて 頂きたい. 
(A)
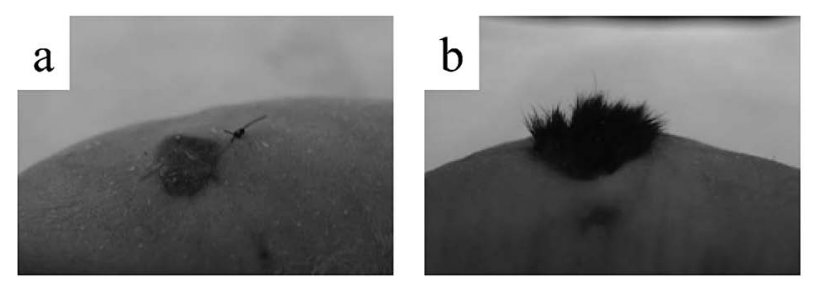

移植部位からの発毛

(B)

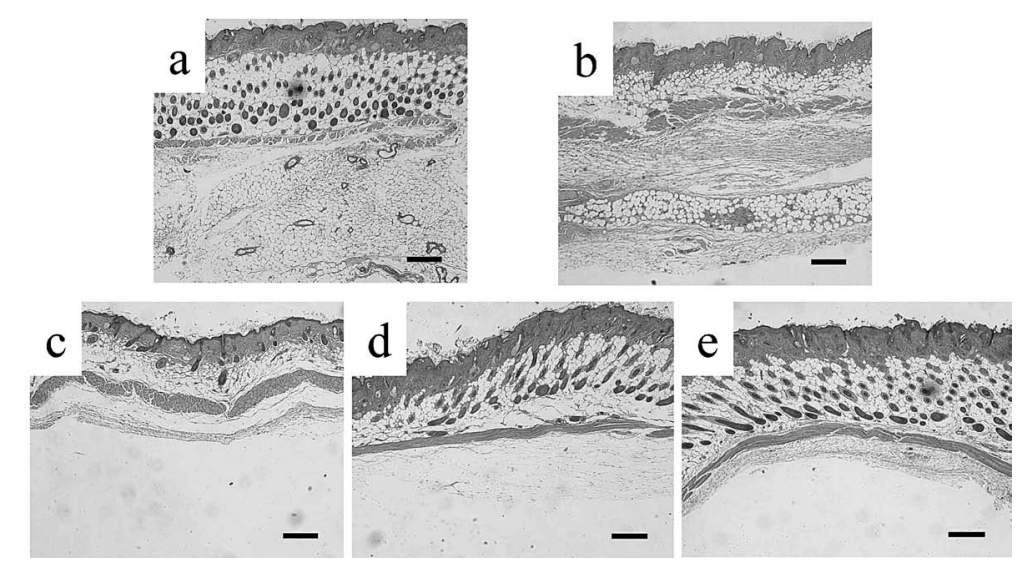

Fig. 7. Induction of Tissue Regeneration by the Combination of Cells, the Scaffold, and the Controlled Release Technology of bFGF from Gelatin Hydrogels

(A) Macroscopic appearance after subcutaneous implantation of a collagen sponge (a) and a collagen sponge reinforced with polyglycolic acid fibers (b) which was seeded with hair follicle cells. Significant cells-induced hair regeneration was observed by the fiber reinforcement of collagen sponge. (B) De novo formation of adipose tissue in the mouse subcutis 6 weeks after implantation of a collagen sponge including human preadipocytes and gelatin microspheres incorporating bFGF: (a) a collagen sponge including the mixture of preadipocytes and gelatin microspheres incorporating bFGF, (b) a collagen sponge including the mixture of preadipocytes and bFGF in the solution form, (c) a collagen sponge including preadipocytes, (d) a mixture of preadipocytes and gelatin microspheres incorporating bFGF, and (e) a collagen sponge including gelatin microspheres incorporating bFGF. (Hematoxylin and eosin staining) The bFGF dose was $1 \mu \mathrm{g} / \mathrm{site}$ and the hydrogel water content was $95.0 \mathrm{wt} \%$. (Bar $=300 \mu \mathrm{m})$

\section{REFERENCES}

1) Taga T., Nakahata T., "Jikkennigaku Zoukangou," No. 24 Yodo-sha, Osaka, 2006.

2) Tabata Y., "Koko made Susunda Saiseiiryou no Jissai," Yodo-sha, 2003.

3) Tabata Y., Tissue Eng., 9(Suppl 1), S5-15 (2003).

4) Tabata Y., "Idenshiigaku MOOK," No. 1, Medical Do, Osaka, 2004.

5) Tabata Y., Drug Discov. Today, 10, 16391646 (2005).

6) Tabata Y., Drug Deliv. Syst., 20, 83-137 (2005).

7) Tabata Y., Companion Anim. Pract. (CAP), 176, 28-35 (2004).

8) Tabata Y., Nihon shikaishikai zasshi, 55, 303317 (2002).
9) Tabata Y., Pharm. Med., 18, 69-74 (2000).

10) Tabata Y., Connect. Tissue, 33, 315-324 (2001).

11) Tabata Y., THE BONE, 17, 29-34 (2003).

12) Tabata Y., Rinnsho Ganka, 59, 229 (2005).

13) Tabata Y., "Tanpakushitu Kakusan Kouso," 45, 2179-2187 (2000).

14) Tabata Y., "Doraggu Deribari-Sisutemu DDS Gijutu no Aratana Tenkai to sono Katsuyou Hou," Idenshiigaku bessatsu, 2003.

15) Tabata Y., Pharm. Sci. Tech. Today, 3, 80-89 (2000) .

16) Gombotz W. R., Pettit D. K., Bioconjug. Chem., 6, 332-351 (1995).

17) Ikada Y., Tabata Y., Adv. Drug Deliv. Rev., 31, 287-301 (1998).

18) Taipale J., Keski-Oja J., FASEB J., 11, 51-59 (1997). 
19) Munniruzzaman M., "Protein Interaction with Gelatin Hydrogels for Tissue Engneering," Trans Tech Publication, Switzerland, 1997, p. 89.

20) Tabata Y., Nagano A., Muniruzzaman M., Ikada Y., Biomaterials, 19, 1781-1789 (1998) .

21) Tabata Y., Nagano A., Ikada Y., Tissue Eng., 5, 127-138 (1999).

22) Kushibiki T., Nagata-Nakajima N., Sugai M., Shimizu A., Tabata Y., J. Control. Release, 110, 610-617 (2006).

23) Hirose K., Marui A., Tabata Y., Komeda M., Pharm. Med., 23, 41-45 (2005).

24) Hatano T., Miyamoto S., Kawakami O., Yamada K., Hashimoto N., Tabata Y., Neurosurgery, 53, 393-400 (2003).

25) Kawakami O., Miyamoto S., Hatano T., Yamada K., Hashimoto N., Tabata Y., Neurosurgery, 58, 355-364 (2006).
26) Harashima H., Tabata Y., "Idenshiigaku MOOK5,' Medical Do, Osaka, 2005.

27) Kushibiki T., Tabata Y., Curr. Drug Deliv., 1, 153-163 (2004).

28) Nagaya N., Kangawa K., Kanda M., Uematsu M., Horio T., Fukuyama N., Hino J., Harada-Shiba M., Okumura H., Tabata Y., Mochizuki N., Chiba Y., Nishioka K., Miyatake K., Asahara T., Hara H., Mori H., Circulation, 108, 889-895 (2003).

29) Okazaki A., Jo J. I., Tabata Y., Tissue Eng., 13, 245-251 (2007).

30) Aoyama T., Yamamoto S., Kanematsu A., Ogawa O., Tabata Y., Tissue Eng., 9, 12891299 (2003).

31) Oe S., Fukunaka Y., Hirose T., Yamaoka Y., Tabata Y., J. Control. Release, 88, 193-200 (2003). 